\title{
Analisis pada Mortar dengan Campuran Lusi, Tanah Sawah, Semen dan Fly Ash Ditinjau terhadap Kuat Tekan dan Resapan
}

\author{
Srie Subekti, Boedi Wibowo \\ Program Studi Diploma Teknik Sipil FTSP ITS, Surabaya \\ Email:subektisrie@gmail.com,boewi_boy@yahoo.com
}

\begin{abstract}
In Porong area, Sidoarjo-East Java, Banjar Panji-well was leak because of PT Lapindo Brantas Inc.drilling, squirting warm mud longer than 8 meter at 29 Mei 2006. Every day it can bringging out 40.000 meter kubik oferflow warm mud wich stagnant vilage and some road Surabaya-Gempol KM 37 and KM 38. The big amount of Sidoarjo Mud will be use for mortar, which need soil farm and another addition for a stabilizer. Cement and fly ash has been used as variation of bound-material with variation compotition of mixing, which can increase the quality of the mortar. This preliminary study is hoped to gift an alternative solution of the used of Sidoarjo-Mud as a materials. As the result of the experiment, we get maximum depress at composition of $40 \%$ soil farm, $51 \%$ sidoarjo-mud and $9 \%$ of cement with about $32.54 \mathrm{~kg} / \mathrm{cm}^{2}$ of depress and $2,10 \%$ water absorb value.
\end{abstract}

Keywords: absorb quality, fly ash, stress strength, Sidoarjo mud, mortar and higher quality, soil farm, PC (portland cement).

Abstrak

Kawasan Porong Sidoarjo, Jawa Timur karena bocornya Sumur Banjar Panji akibat pengeboran oleh PT Lapindo Brantas Inc., menyemburkan lumpur panas setinggi delapan meter pada 29 Mei 2006. Sumur ini setiap harinya dapat mengeluarkan 40000 meter kubik lumpur panas yang menggenangi Desa dan jalan tol Surabaya-Gempol KM 37 dan KM 38. Lumpur Sidoarjo dan volume yang sangat besar itu akan dimanfaatkan sebagai mortar, untuk stabilitas diperlukan penambahan tanah sawah dan bahan pendukung lain. Penambahan semen dan fly ash sebagai bahan pengikat dengan variasi komposisi campuran tertentu diharapkan dapat meningkatkan mutu mortar. Diharapkan study awal ini mampu memberikan solusi mengenai efisiensi dan fungsi optimal dari penggunaan lumpur sidoarjo sebagai alternatif bahan bangunan. Dari hasil penelitian didapat bahwa, kuat tekan maksimum mortar pada campuran 40\% tanah sawah $51 \%$ lumpur dan 9\% semen dengan nilai kuat tekan rata-rata sebesar 32,54 $\mathrm{kg} / \mathrm{cm}^{2}$ dan resapan air sebesar $2,10 \%$.

Kata kunci: daya serap, fly ash, kuat tekan, lumpur sidoarjo, mortar dan peningkatan mutu, tanah sawah, PC (Portland Cement).

\section{Pendahuluan}

\subsection{Latar Belakang}

Kawasan Porong Sidoarjo, Jawa Timur karena bocornya Sumur Banjar Panji akibat pengeboran oleh PT Lapindo Brantas Inc., menyemburkan lumpur panas setinggi delapan meter pada 29 Mei 2006. Sumur ini setiap harinya dapat mengeluarkan 40.000 meter kubik lumpur panas yang menggenangi Desa dan jalan tol Surabaya-Gempol KM 37 dan KM 38. Lumpur Sidoarjo dengan volume yang sangat besar itu akan dimanfaatkan sebagai penelitian studi awal dengan pembuatan mortar, untuk stabilitas diperlukan penambahan tanah sawah dan bahan pendukung lain. Penambahan semen dan fly ash sebagai bahan pengikat dengan variasai 
komposisi tertentu diharapkan dapat meningkatkan mutu mortar.

Penelitian ini bertujuan untuk mendapatkan nilai resapan minimum mortar dari variasi komposisi canpuran lumpur sidoarjo, tanah sawah, fly ash dan semen yang memiliki kuat tekan maksimum. Serta untuk mendapatkan kuat tekan maksimum mortar dari campuran lumpur sidoarjo, tanah sawah, fly ash dan semen sesuai prosentase yang dirancang.

Dalam penelitian ini digunakan campuran Lumpur Sidoarjo, tanah sawah Fly Ash dan semen untuk pembuatan mortar. Semen yang digunakan adalah Semen Gresik tipe I. Sedangkan mortar yang dibuat dari campuran Lumpur Sidoarjo, tanah sawah, fly ash dan semen diuji kuat tekan sesuai dengan Standart Nasional Indonesia 15-2094-1991.

\section{Metodologi}

\subsection{Lumpur Sidoarjo}

Adapun karakteristik lumpur Sidoarjo ialah:

\section{Karakteristik Fisik}

Menurut Jogie dan Agung (Metcalf dan Eddy,1979) yaitu: Grit Chamber: Pada Grit Chamber biasanya terdiri dari endapan anorganik dan mengandung sedikit bahan organik.

2. Karakteristik Kimia

\subsection{Tanah Sawah}

Tanah sawah, lempung atau tanah liat menurut (Braja.1991), merupakan hasil pelapukan dari batuan keras, seperti batuan basalt (batuan dasar), andesit dan granit (batuan besi). Tanah sawah yang digunakan adalah tanah sawah daerah Mojotamping yang biasa dibuat batu bata.

Tabel 1. Karakteristik Lumpur

\begin{tabular}{cc}
\hline PARAMETER & $\begin{array}{c}\text { KONSENTRASI } \\
(\%)\end{array}$ \\
\hline $\mathrm{CaO}$ & 22.25 \\
\hline $\mathrm{MgO}$ & 5.1 \\
\hline $\mathrm{Fe}_{2} \mathrm{O}_{3}$ & 5.85 \\
\hline $\mathrm{Al}_{2} \mathrm{O}_{2}$ & 16.8 \\
\hline $\mathrm{SiO}_{2}$ & 26.31 \\
\hline $\mathrm{H}_{2} \mathrm{O}$ & 22.16 \\
\hline
\end{tabular}

Sumber: BPKI 2006

Tabel 2. Karakteristik Tanah Sawah

\begin{tabular}{cc}
\hline PARAMETER & $\begin{array}{c}\text { KONSENTRASI } \\
(\%)\end{array}$ \\
\hline $\mathrm{CaO}$ & 26.44 \\
\hline $\mathrm{MgO}$ & 5.56 \\
\hline $\mathrm{SiO}_{2}$ & 23.23 \\
\hline $\mathrm{Al}_{2} \mathrm{O}_{2}$ & 14.46 \\
\hline $\mathrm{FE}_{2} \mathrm{O}_{3}$ & 12.88 \\
\hline $\mathrm{H}_{2} \mathrm{O}$ & 17.4 \\
\hline
\end{tabular}

Sumber: BPKI.2006

Sifat - Sifat Lempung

1. Sifat Plastis

Sifat plastis mudah dibentuk. Sifat plastis timbul bila lempung ditambah air pada kebutuhan tepat.

2. Kekuatan kering

Kekuatan kering timbul setelah lempung dikeringkan.

3. Susut kering

Dalam proses pembuatan batu bata, lempung ditambah dengan air agar menjadi plastis dan mudah dibentuk.

\subsection{Semen Portland}

Secara umum semen dapat didefinisikan 
sebagai bahan organik yang mengeras bila pencampurannya dengan air. Sedangkan, menurut SII 0013-1981, Semen Portland adalah bahan hidrolis yang dihasilkan dengan cara menghaluskan klinker (terak semen portland).

\subsection{Fly Ash}

Dalam fly ash mengandung beberapa komposisi kimia, antara lain seperti pada tabel 4.

Tabel 3. Hasil Uji Fisik Semen Portland Type I

\begin{tabular}{cccc}
\hline Senyawa Kimia & $\begin{array}{c}\text { Prosentase } \\
(\%)\end{array}$ & $\begin{array}{c}\text { SNI 15- } \\
2049-94\end{array}$ & Ket \\
\hline $\begin{array}{c}\text { Silikon Dioksida } \\
\left(\mathrm{SiO}_{2}\right)\end{array}$ & 20.82 & - & OK \\
\hline $\begin{array}{c}\text { Alumunium Oksida } \\
\left(\mathrm{Al}_{2} \mathrm{O}_{3}\right)\end{array}$ & 5.56 & - & OK \\
\hline $\begin{array}{c}\text { Ferri Oksida } \\
\left(\mathrm{Fe}_{2} \mathrm{O}_{3}\right)\end{array}$ & 3.76 & - & \\
\hline $\begin{array}{c}\text { Kalium Oksida } \\
(\mathrm{CaO})\end{array}$ & 64.7 & - \\
\hline $\begin{array}{c}\text { Magnesium Oksida } \\
(\mathrm{MgO})\end{array}$ & 0.97 & $5 \%$ \\
\hline $\begin{array}{c}\text { Sulfur Oksida } \\
(\mathrm{SO})\end{array}$ & 2.3 & $3.50 \%$ \\
\hline $\begin{array}{c}\text { Trikalsim Silikat } \\
\left(\mathrm{C}_{3} \mathrm{~S}\right)\end{array}$ & 56.11 & - \\
\hline $\begin{array}{c}\text { Dikalsium Silikat } \\
\left(\mathrm{C}_{2} \mathrm{~S}\right)\end{array}$ & 17.37 & - \\
\hline $\begin{array}{c}\text { Trikalsium Aluminat } \\
\left(\mathrm{C}_{3} \mathrm{Al}\right)\end{array}$ & 8.34 & - \\
\hline $\begin{array}{c}\text { Tetrakalsium Aluminat } \\
\text { Ferrit }\left(\mathrm{C}_{4} \mathrm{AlF}\right)\end{array}$ & 11.52 & - \\
\hline Sumber: PT. Smen Gresik &
\end{tabular}

Dengan penambahan Fly Ash akan berakibat pada struktur beton, hal-hal sbb:

1. Curing time (umur 90 hari) laju reaksi pozzolanic pengikatan $\mathrm{Ca}(\mathrm{OH})_{2}$ yang akan berinteraksi dengan $\mathrm{CO}_{2}$ berkurang karena karbonasi terhambat. Menurut Aman Subekti (mix beton dasar) bahwa curring time umur 90 hari dipakai untuk menentukan mutu tinggi dan karakteristik beton, dengan memodifikasi perbandingan komponen semen.

2. Menurunkan alkalinitas beton yang merupakan penyebab terjadinya korosi pada besi beton.

Tabel 4. Komposisi Kimia Fly Ash

\begin{tabular}{cc}
\hline PARAMETER & KONSENTRASI (\%) \\
\hline $\mathrm{SiO}_{2}$ & 52 \\
\hline $\mathrm{Al}_{2} \mathrm{O}_{3}$ & 31.86 \\
\hline $\mathrm{Fe}_{2} \mathrm{O}_{3}$ & 4.89 \\
\hline $\mathrm{CaO}$ & 2.68 \\
\hline $\mathrm{MgO}$ & 4.66 \\
\hline
\end{tabular}

\subsection{Air}

Air yang digunakan untuk campuran mortar adalah air PDAM. Hasil uji fisik dan kimia air dapat dilihat pada tabel 5 dan 6 yang dilakukan PT.Varia Usaha.

Tabel 5. Hasil Uji Fisik Air

\begin{tabular}{cccc}
\hline Uji Fisik & $\begin{array}{c}\text { Air } \\
\text { PDAM } \\
\text { Surabaya }\end{array}$ & $\begin{array}{c}\text { PERMENKES } \\
\text { RI No. } \\
\text { 416/MENKES } \\
\text { Per IX/90 }\end{array}$ & Ket \\
\hline $\begin{array}{c}\text { Warna } \\
\text { (unit Pt Co) }\end{array}$ & 6.21 & 50 & \\
\hline Rasa & $\begin{array}{c}\text { Tak } \\
\text { Berasa }\end{array}$ & Tak Berasa & OK \\
\hline $\begin{array}{c}\text { Tak } \\
\text { Berbau }\end{array}$ & Tak Berbau & OK \\
\hline $\begin{array}{c}\text { Kekeruhan } \\
\text { (Skala NTU) }\end{array}$ & 241 & $15-J a n$ & OK \\
\hline $\begin{array}{c}\text { Padatan } \\
\text { Terlarut } \\
\text { (ppm) }\end{array}$ & 20 & 1000 & OK \\
\hline $\begin{array}{c}\text { Jumlah } \\
\text { Padatan }\end{array}$ & 260 & 1500 & OK \\
\hline $\begin{array}{l}\text { Sumber: Oktavia } \\
\text { Bumber }\end{array}$ & &
\end{tabular}

\subsection{Teori Mengenai Benda Uji} Mortar

Menurut SNI 03-6825-2002 mortar adalah suatu komposisi bahan yang 
dibuat dari semen dan agregat halus yang dicampur dengan air.

1. Cara Pembuatan

Dalam pembuatan mortar pengadukan campuran dan pencetakan bisa dilakukan secara manual yaitu dengan tangan.

2. Syarat Mutu

\section{a. Sifat Tampak}

Mortar harus mempunyai bentuk yang sempurna yaitu kubus, tidak terdapat retak-retak dan cacat.

b. Bentuk dan Ukuran

Bentuk dan ukuran mortar adalah kubus dengan dimensi ukuran $5 \mathrm{~cm}$ $\mathrm{x} 5 \mathrm{~cm} \times 5 \mathrm{~cm}$.

Tabel 6. Hasil Uji Kimia Air

\begin{tabular}{lccc}
\hline \multicolumn{1}{c}{ Uji Kimia } & $\begin{array}{c}\text { Air } \\
\text { PDAM } \\
\text { Surabaya }\end{array}$ & PBI 71 & Ket \\
\hline $\begin{array}{l}\text { Calsium } \\
\left(\mathrm{CaCO}_{3}\right)\end{array}$ & 136.27 & Max 500 & OK \\
\hline $\begin{array}{l}\text { Magnesium } \\
(\mathrm{Mg})\end{array}$ & 9.65 & Max 150 & OK \\
\hline Alkali & 79.32 & Max 500 & OK \\
\hline Natrium $(\mathrm{Na})$ & - & - & OK \\
\hline Kalium & - & - & OK \\
\hline Bikarbonat & - & - & OK \\
\hline Sulfat $\left(\mathrm{SO}_{4}\right)$ & 37.12 & Max 400 & OK \\
\hline Chlorida $(\mathrm{Cl})$ & 37.94 & Max 250 & OK \\
\hline Nitrat $\left(\mathrm{NO}_{3}\right)$ & 0.07 & Max 10 & OK \\
\hline Carbonat & - & - & OK \\
\hline Sumber: Oktavia & & &
\end{tabular}

\subsection{Pengujian Material Utama}

Dalam menguji lumpur dan tanah sawah menggunakan pemeriksaan kadar air dengan Metode Attenberg. Metode Attenberg digunakan untuk mengetahui batas-batas konsistensi tanah berdasarkan kadar airnya (Braja. 1991),
Mekanika Tanah jilid 1 (Prinsip-Prinsip Rekayasa Geotehnis, Erlangga, Jakarta, 1991). Terdiri dari:

a. Batas Cair (Liquid Limit_LL)

Adalah batas kadar air dimana tanah berubah dari keadaan cair ke keadaan plastis.

Menurut sumner yang didapatkan dari Djatmiko. 1997 perhitungannya adalah sebagai berikut;

Menentukan kadar air (Wc) data dari batas cair:

$W c=\frac{W 2-W 3}{W 3-W 1} \times 100 \%$

Dimana:

$\mathrm{W}_{1}=$ Berat cawan

$\mathrm{W}_{2}=$ Berat cawan + Tanah basah

$\mathrm{W}_{3}=$ Berat cawan + Tanah kering

b. Batas Plastis (Plastic Limit-PL)

Adalah batas kadar air dimana tanah berubah dari keadaan plastis ke keadaan semi solid.

Perhitungan menurut Djatmiko. 1997:

$$
\mathrm{PL}=\frac{W_{2}-W_{3}}{W_{3}-W_{1}} \times 100 \%
$$

Dimana:

$\mathrm{W}_{1}=$ Berat cawan

$\mathrm{W}_{2}=$ Berat cawan + Tanah basah

$\mathrm{W}_{3}=$ Berat cawan + Tanah kering

c. Batas Susut (Shrinkage Limit-SL)

Adalah batas kadar air dimana tidak mengalami penambahan penyusutan dari volume tanah. Djatmiko. 1997 dapat digunakan persamaan sebagai berikut:

Batas susut (SL) $\omega-\left(\frac{V-V o}{W o} \times 100 \%\right)$ 
Dimana :

$\omega=$ Kadar air

$\mathrm{V}=$ Volume benda uji basah

$\mathrm{Vo}=$ Volume benda uji kering

$\mathrm{Wo}=$ Berat benda uji kering

\subsection{Proses Pembuatan Benda Uji}

1. Pengambilan Bahan Dasar

Lumpur yang diambil adalah lumpur yang mempunyai kadar air cukup tinggi.

2. Persiapan Pengolahan Bahan

Setelah kedua bahan dasar tersebut kering, lumpur yang sudah kering ditumbuk sampai halus kemudian diayak. Begitu juga dengan tanah sawah. Dalam pencampuran bahan, lumpur ditimbang sesuai komposisi dicampur dengan tanah sawah, kemudian dicampur semen dan fly ash sesuai komposisi. Bahan yang sudah tercampur rata sesuai dengan perbandingan komposisi yang diklasifikasikan menurut mutu yang telah disyaratkan dalam SNI 030691-1996, diaduk menggunakan tangan dengan menambahkan air sedikit demi sedikit sampai diperoleh campuran bahan yang homogen.

3. Pencetakan Benda Uji Mortar

Benda uji mortar dibuat berdasarkan SNI 03-00349-1989 dan SNI 028580. Dimensi mortar yang digunakan dalam penelitian ini $(5 \times 5 \times 5) \mathrm{cm}$ :

a. Sebelum mortar dicetak, cetakan harus bersih dan diolesi oli.

b. Tiga puluh detik setelah pengadukan campuran tadi dimasukkan dalam cetakan lapis perlapis sebanyak tiga lapis dan setiap lapis dipadatkan dengan25 kali rojokan.

c. Ratakan permukaan mortar dengan cara ditekan dengan balok kayu yang dibuat sesuai ukuran permukaan cetakan mortar.

d. Diamkan mortar selama 20 jam sampai mortar mengeras.

e. Setelah benda uji mengeras, lepaskan dari cetakannya.

f. Penyimpanan dan perawatan benda uji mortar dilakukan dengan cara direndam dalam air.

4. Penyimpanan Benda Uji Mortar

Penyimpanan atau perawatan benda uji yang digunakan dalam penelitian ini adalah, setelah cetakan dibuka, mortar direndam kedalam air.

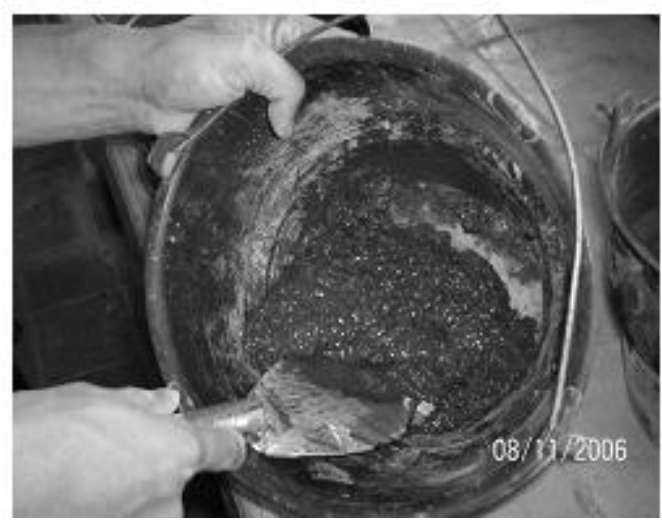

Gambar 1. Pencampuran bahan dasar

\subsection{Pengujian Resapan Benda Uji Mortar}

Pengujian resapan benda uji mortar untuk mengetahui berapa besar pengaruh daya resap dari mortar pada umur 7, 14 dan 28 hari. Pengujian resapan mortar ukuran $(5 \times 5 \times 5) \mathrm{cm}$ dilaksanakan di Laboratorium Uji Beton 
D3 Teknik Sipil - ITS.

$$
\left[\frac{W_{\text {basah }}-W_{\text {Kering }}}{W_{\text {basah }}}\right] \times 100 \%
$$

\subsection{Pengujian Kuat Tekan Benda Uji Mortar}

Dengan menekan mortar arah vertikal dari atas dan bawah sampai benda uji hancur. Pengujian kuat tekan dilakukan di kampus DIII - Teknik Sipil ITS, dengan umur benda uji 7, 14 dan 28 hari.

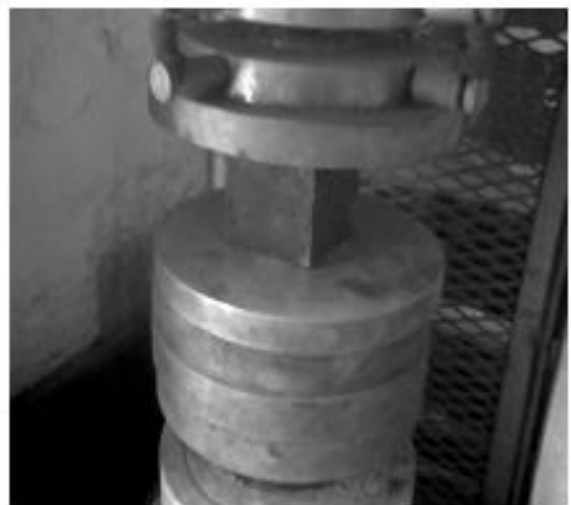

Gambar 2. Uji tekan mortar

\subsection{Analisis}

Maksud dari pemeriksaan kuat tekan adalah untuk mengetahui kuat tekan dari benda uji mortar. Penyerapan air adalah untuk mengetahui banyaknya air yang dapat diserap oleh mortar.

\subsection{Kesimpulan}

Dari hasil komposisi yang direncanakan diperoleh nilai kuat tekan maksimal dan nilai resapan minimal dari campuran lumpur sidoarjo, tanah sawah, fly ash dan semen, yang selanjutnya dipakai sebagai material alternatif.

\section{Hasil dan Pembahasan}

\subsection{Test Attenberg}

Tujuan dari dilakukan Test Attenberg adalah menggambarkan batas-batas konsistensi dari tanah berbutir halus dengan mempertimbangkan kandungan kadar airnya. Batas-batas tersebut adalah batas cair, batas plastis dan batas susut.

1. Batas Cair (Liquid Limit-LL)

Menentukan kadar air (Wc) data dari batas cair.

$\mathrm{Wc}=\frac{W_{2}-W_{3}}{W_{3}-W_{1}} \times 100 \%$

Dimana:

$\mathrm{W}_{1}=$ Berat cawan

$\mathrm{W}_{2}=$ Berat cawan + Tanah basah

$\mathrm{W}_{3}=$ Berat cawan + Tanah kering

Tabel 7. Campuran 40\% Lumpur $+60 \%$ Tanah Sawah

\begin{tabular}{|c|c|c|c|c|c|}
\hline No & Test & 1 & 2 & 3 & 4 \\
\hline 1 & No. cawan & 23 & 100 & 4 & 27 \\
\hline 2 & Berat cawan $\left(\mathrm{W}_{1}\right)$ & 47.9 & 48.9 & 33 & 35.5 \\
\hline 3 & $\begin{array}{c}\text { Berat cawan }+ \\
\text { Tanah basah }\left(\mathrm{W}_{2}\right)\end{array}$ & 88 & 79.3 & 72.4 & 64.5 \\
\hline 4 & $\begin{array}{c}\text { Berat cawan }+ \\
\text { Tanah kering }\left(\mathrm{W}_{3}\right)\end{array}$ & 72.1 & 64.1 & 57.5 & 50 \\
\hline 5 & Berat air (gram) & 15.9 & 15.2 & 14.9 & 14.5 \\
\hline 6 & $\begin{array}{c}\text { Berat tanah kering } \\
\text { (gram) }\end{array}$ & 24.2 & 25.3 & 24.5 & 26.3 \\
\hline 7 & $\begin{array}{c}\text { Jumlah Pukulan } \\
\text { (N) }\end{array}$ & 12 & 19 & 27 & 40 \\
\hline 8 & Kadar air \% & 65.7 & 60.1 & 61 & 55.1 \\
\hline
\end{tabular}

2. Batas Plastis (Plastic Limit-PL)

Menentukan kadar plastis ( PL ):

$$
\mathrm{PL}=\frac{W_{2}-W_{3}}{W_{3}-W_{1}} x 100 \%
$$

Dimana:

$\mathrm{W}_{1}=$ Berat cawan

$\mathrm{W}_{2}=$ Berat cawan + Tanah basah

$\mathrm{W}_{3}=$ Berat cawan + Tanah kering 
Tabel 8. Campuran 50\% Lumpur $+50 \%$

Tanah Sawah

\begin{tabular}{cccccc}
\hline No & Test & 1 & 2 & 3 & 4 \\
\hline 1 & No. cawan & 17 & 10 & 7 & 5 \\
\hline 2 & Berat cawan $\left(\mathrm{W}_{1}\right)$ & 48.1 & 50 & 48.8 & 39.4 \\
\hline & $\begin{array}{c}\text { Berat cawan + Tanah } \\
\text { basah }\left(\mathrm{W}_{2}\right)\end{array}$ & 88.2 & 89.8 & 87.6 & 79.7 \\
\hline 3 & $\begin{array}{c}\text { Berat cawan + Tanah } \\
\text { kering (W })\end{array}$ & 72.2 & 74.2 & 72.5 & 64.3 \\
\hline 4 & Berat air (gram) & 16 & 15.6 & 15.1 & 15.4 \\
\hline 5 & $\begin{array}{c}\text { Berat tanah kering } \\
\text { (gram) }\end{array}$ & 24.1 & 24.2 & 23.7 & 24.9 \\
\hline 6 & Jumlah Pukulan (N) & 18 & 20 & 37 & 45 \\
\hline 8 & Kadar air \% & 66.3 & 64.5 & 63.6 & 62 \\
\hline & \multicolumn{2}{c}{ Didapat LL $=65.29 \%$}
\end{tabular}

Tabel 9. Campuran 55\% Lumpur $+45 \%$

Tanah Sawah

\begin{tabular}{cccccc}
\hline No & Test & 1 & 2 & 3 & 4 \\
\hline 1 & No. cawan & 15 & 1 & 9 & 3 \\
\hline 2 & Berat cawan $\left(\mathrm{W}_{1}\right)$ & 40 & 48.6 & 36.8 & 50 \\
\hline & $\begin{array}{c}\text { Berat cawan }+ \\
\text { Tanah basah }\left(\mathrm{W}_{2}\right)\end{array}$ & 80 & 87.8 & 76.8 & 89.9 \\
\hline & $\begin{array}{c}\text { Berat cawan }+ \\
\text { Tanah kering } \\
\left(\mathrm{W}_{3}\right)\end{array}$ & 64 & 72 & 61.3 & 74.4 \\
\hline 4 & Berat air (gram) & 16 & 15.8 & 15.5 & 15.5 \\
\hline 5 & $\begin{array}{c}\text { Berat tanah kering } \\
\text { (gram) }\end{array}$ & 24 & 23.4 & 24.5 & 24.4 \\
\hline 6 & $\begin{array}{c}\text { Jumlah Pukulan } \\
(\mathrm{N})\end{array}$ & 13 & 17 & 34 & 44 \\
\hline 8 & Kadar air \% & 67 & 67.6 & 63.2 & 63.6 \\
\hline \multicolumn{4}{c}{ Didapat LL $=66.4 \%$}
\end{tabular}

Tabel 10. Campuran 60\% Lumpur + 40\% Tanah Sawah

\begin{tabular}{cccccc}
\hline No & Test & 1 & 2 & 3 & 4 \\
\hline 1 & No. cawan & 17 & 5 & 7 & 10 \\
\hline 2 & Berat cawan (W1) & 47.1 & 39.4 & 48.1 & 50 \\
\hline & $\begin{array}{c}\text { Berat cawan + Tanah } \\
\text { basah (W2) }\end{array}$ & 86.1 & 79.6 & 88.2 & 90.1 \\
\hline 3 & $\begin{array}{c}\text { Berat cawan + Tanah } \\
\text { kering (W3) }\end{array}$ & 70.7 & 63.5 & 72 & 74.2 \\
\hline 4 & Berat air (gram) & 15.4 & 16.1 & 16.2 & 15.9 \\
\hline 5 & $\begin{array}{c}\text { Berat tanah kering } \\
\text { (gram) }\end{array}$ & 23.6 & 24.1 & 23.9 & 24.2 \\
\hline 6 & Jumlah Pukulan (N) & 17 & 20 & 30 & 41 \\
\hline 8 & Kadar air \% & 69.5 & 67 & 67.7 & 65.7 \\
\hline & \multicolumn{2}{c}{ Didapat LL $=68.36 \%$}
\end{tabular}

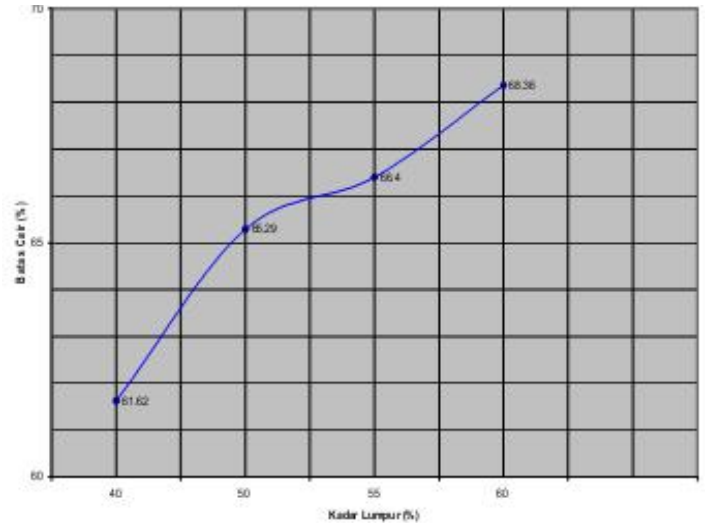

Gambar 3. Grafik hubungan antara batas cair dan lumpur

Tabel 11. Campuran 40\% Lumpur $+60 \%$ Tanah Sawah

\begin{tabular}{cccc}
\hline No & Test & 1 & 2 \\
\hline 1 & No. cawan & 16 & 3 \\
\hline 2 & Berat cawan $\left(\mathrm{W}_{1}\right)$ & 48.1 & 48.7 \\
\hline 3 & Berat cawan + Tanah basah $\left(\mathrm{W}_{2}\right)$ & 72.1 & 71.7 \\
\hline 4 & $\begin{array}{c}\text { Berat cawan + Tanah kering } \\
\left(\mathrm{W}_{3}\right)\end{array}$ & 53.6 & 65.5 \\
\hline 5 & Berat air (gram) & 5.5 & 6.2 \\
\hline 6 & Berat tanah kering (gram) & 18.5 & 16.8 \\
\hline 7 & Kadar air \% & 29.9 & 36.2 \\
\hline
\end{tabular}

Tabel 12. Campuran 50\% Lumpur + 50\% Tanah Sawah

\begin{tabular}{cccc}
\hline No & Test & 1 & 2 \\
\hline 1 & No. cawan & 24 & 36 \\
\hline 2 & Berat cawan $\left(\mathrm{W}_{1}\right)$ & 50 & 40.5 \\
\hline 3 & Berat cawan + Tanah basah $\left(\mathrm{W}_{2}\right)$ & 72 & 63.2 \\
\hline 4 & Berat cawan + Tanah kering $\left(\mathrm{W}_{3}\right)$ & 67.5 & 57.6 \\
\hline 5 & Berat air $($ gram $)$ & 4.5 & 5.6 \\
\hline 6 & Berat tanah kering (gram) & 17.5 & 17.1 \\
\hline 7 & Kadar air \% & 26.9 & 30.9 \\
\hline
\end{tabular}

Tabel 13. Campuran 55\% Lumpur + 45\% Tanah Sawah

\begin{tabular}{cccc}
\hline No & Test & 1 & 2 \\
\hline 1 & No. cawan & 5 & 36 \\
\hline 2 & Berat cawan $\left(\mathrm{W}_{1}\right)$ & 132 & 40.5 \\
\hline 3 & Berat cawan + Tanah basah $\left(\mathrm{W}_{2}\right)$ & 154 & 63.3 \\
\hline 4 & Berat cawan + Tanah kering $\left(\mathrm{W}_{3}\right)$ & 149 & 58.4 \\
\hline 5 & Berat air (gram) & 4.5 & 4.9 \\
\hline 6 & Berat tanah kering (gram) & 17.4 & 17.9 \\
\hline 7 & Kadar air \% & 25.9 & 28.3 \\
\hline
\end{tabular}

3. Batas Susut (Shrinkage Limit-SL) Menentukan Batas Susut ( SL) : 
Batas susut $(\mathrm{SL})=\omega-\left(\frac{V-V o}{W o} \times 100 \%\right)$

Dimana :

$\omega=$ Kadar air

$\mathrm{V}=$ Volume benda uji basah

$V_{o}=$ Volume benda uji kering

$\mathrm{Wo}=$ Berat benda uji kering

Tabel 14. Campuran 60\% Lumpur + 40\% Tanah Sawah

\begin{tabular}{cccc}
\hline No & Test & 1 & 2 \\
\hline 1 & No. cawan & 16 & 5 \\
\hline 2 & Berat cawan $\left(\mathrm{W}_{1}\right)$ & 48.1 & 132 \\
\hline 3 & Berat cawan + Tanah basah $\left(\mathrm{W}_{2}\right)$ & 70.4 & 154 \\
\hline 4 & Berat cawan + Tanah kering $\left(\mathrm{W}_{3}\right)$ & 66.2 & 150 \\
\hline 5 & Berat air (gram) & 4.2 & 4.6 \\
\hline 6 & Berat tanah kering (gram) & 18.1 & 17.8 \\
\hline 7 & Kadar air \% & 23.5 & 27.9 \\
\hline
\end{tabular}

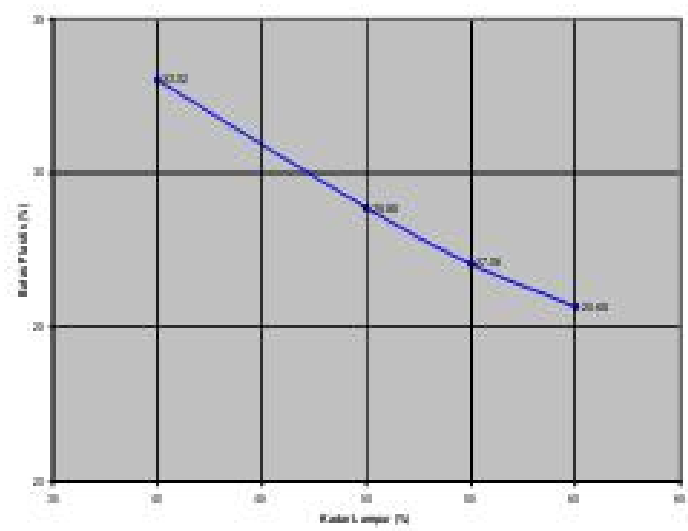

Gambar 4. Grafik hubungan antara batas plastis dan lumpur

Tabel 15. Campuran $40 \%$ Lumpur + $60 \%$ Tanah Sawah

\begin{tabular}{ccc}
\hline No & Test & Hasil \\
\hline 1 & No. Cawan logam & A2 \\
\hline 2 & Berat cawan logam (W1) & 16 \\
\hline 3 & Berat cawan + Hg sudah diratakan & 258 \\
\hline 4 & Berat cawan + tanah basah (W2) & 43.5 \\
\hline 5 & Berat cawan + tanah kering (W3) & 30.8 \\
\hline 6 & Kadar air (\%) & 85.8 \\
\hline 7 & Berat Hg yang dipindahkan (basah) & 242 \\
\hline 8 & Berat Hg yang dipindahkan (kering) & 176 \\
\hline 9 & Volume basah (V) & 17.8 \\
\hline 10 & Volume kering (Vs) & 12.9 \\
\hline 11 & Batas susut & 53
\end{tabular}

Tabel 16. Campuran 50\% Lumpur $+50 \%$ Tanah Sawah

\begin{tabular}{ccc}
\hline No & Test & Hasil \\
\hline 1 & No. Cawan logam & K1 \\
\hline 2 & Berat cawan logam $\left(\mathrm{W}_{1}\right)$ & 19 \\
\hline 3 & Berat cawan + Hg sudah diratakan & 244 \\
\hline 4 & Berat cawan + tanah basah $\left(\mathrm{W}_{2}\right)$ & 47 \\
\hline 5 & Berat cawan + tanah kering $\left(\mathrm{W}_{3}\right)$ & 36 \\
\hline 6 & Kadar air $(\%)$ & 61.7 \\
\hline 7 & Berat Hg yang dipindahkan (basah) & 225 \\
\hline 8 & Berat Hg yang dipindahkan (kering) & 173 \\
\hline 9 & Volume basah (V) & 16.5 \\
\hline 10 & Volume kering (Vs) & 12.7 \\
\hline 11 & Batas susut & 42.2 \\
\hline
\end{tabular}

Tabel 17. Campuran 55\% Lumpur + 45\% Tanah Sawah

\begin{tabular}{ccc}
\hline No & Test & Hasil \\
\hline 1 & No. Cawan logam & B3 \\
\hline 2 & Berat cawan logam $\left(\mathrm{W}_{1}\right)$ & 18.7 \\
\hline 3 & Berat cawan + Hg sudah diratakan & 243 \\
\hline 4 & Berat cawan + tanah basah $\left(\mathrm{W}_{2}\right)$ & 45 \\
\hline 5 & Berat cawan + tanah kering $\left(\mathrm{W}_{3}\right)$ & 35 \\
\hline 6 & Kadar air $(\%)$ & 61.4 \\
\hline 7 & Berat Hg yang dipindahkan (basah) & 224 \\
\hline 8 & Berat Hg yang dipindahkan (kering) & 165 \\
\hline 9 & Volume basah (V) & 16.5 \\
\hline 10 & Volume kering (Vs) & 12.1 \\
\hline 11 & Batas susut & 34.4 \\
\hline
\end{tabular}

Tabel 18. Campuran $60 \%$ Lumpur + 40\% Tanah Sawah

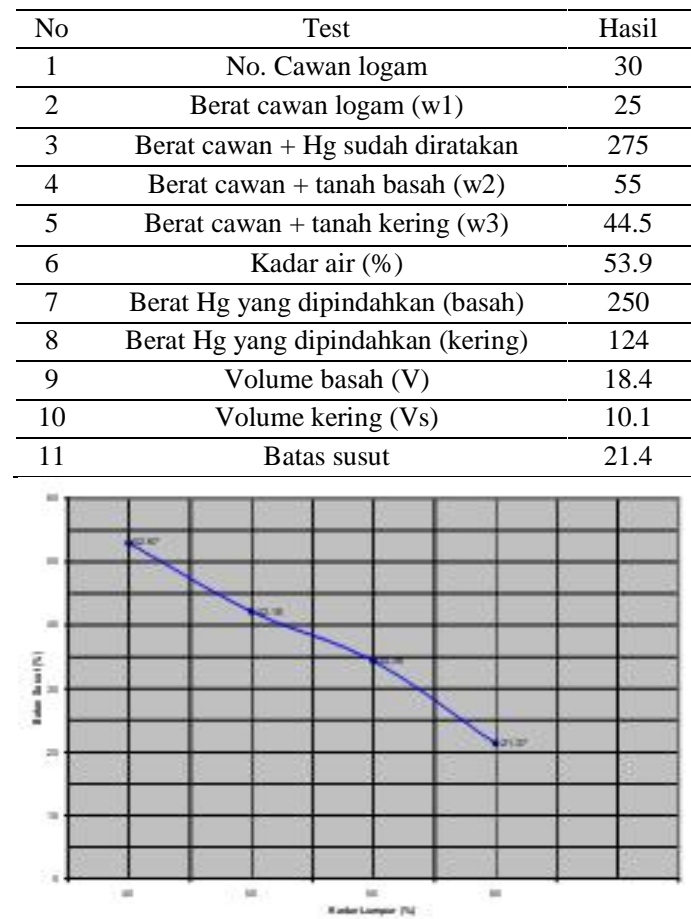

Gambar 5. Grafik hubungan antara batas surut dan lumpur 
4. Plasticity Index (PI)

Indeks plastisitas (IP) adalah selisih batas cair dan batas plastis.

Tabel 19. Nilai Indeks Plastisitas dan Macam Tanah

\begin{tabular}{|c|c|c|c|}
\hline \multirow[b]{2}{*}{ PI } & \multicolumn{3}{|c|}{ Macam } \\
\hline & Sifat & Tanah & Kohesi \\
\hline 0 & Nonplastis & Pasir & Nonkohesif \\
\hline$<7$ & $\begin{array}{l}\text { Plastisitas } \\
\text { rendah }\end{array}$ & Lanau & $\begin{array}{l}\text { Kohesif } \\
\text { sebagian }\end{array}$ \\
\hline $\begin{array}{l}17- \\
\text { Jul }\end{array}$ & $\begin{array}{c}\text { Plastisitas } \\
\text { sedang }\end{array}$ & $\begin{array}{l}\text { Lempung } \\
\text { berlanau }\end{array}$ & Kohesif \\
\hline$>17$ & $\begin{array}{c}\text { Plastisitas } \\
\text { tinggi }\end{array}$ & lempung & Kohesif \\
\hline
\end{tabular}

Sumber: Hary Chritady Hardiyanto, 1992

Tabel 20. Nilai IP dari Komposisi Campuran

\begin{tabular}{cc}
\hline Komposisi Campuran & IP $(\%)$ \\
\hline $40 \%$ Lusi $+60 \%$ T. Sawah & 28.6 \\
\hline $50 \%$ Lusi $+50 \%$ T. Sawah & 36.41 \\
\hline $55 \%$ Lusi $+45 \%$ T. Sawah & 39.34 \\
\hline $60 \%$ Lusi $+40 \%$ T. Sawah & 42.68
\end{tabular}

Batas-batas Atterberg berguna untuk identifikasi dan klasifikasi tanah. Dari percobaan Atterberg diperoleh garis besar sifat tanah yang bersangkutan. Tanah yang memiliki batas cair tinggi yaitu daya dukung tanah rendah, pemampatan tinggi dan sulit memadatkan.

\subsection{Analisa Ayakan}

1. Analisa Ayakan Pasir Lamongan

Tabel 21. Hasil Analisa Ayakan Pasir Lamongan

\begin{tabular}{cccc}
\hline Diameter Ayakan & \multicolumn{3}{c}{ Pasir 1000 gram } \\
\hline $\mathrm{mm}$ & gram & $\%$ & $\mathrm{E} \%$ \\
\hline 4.76 & 0 & 0 & 0 \\
\hline 2.38 & 8 & 0.8 & 0.8 \\
\hline 1.19 & 77.4 & 7.74 & 8.54 \\
\hline 0.59 & 452 & 45.2 & 53.72 \\
\hline 0.3 & 236 & 23.6 & 77.29 \\
\hline 0.15 & 175 & 17.5 & 94.81 \\
\hline 0 & 51.9 & 5.19 & 100 \\
\hline Jumlah & 1000 & 100 & 335.2 \\
\hline & & Fkr $=$ & 3.35 \\
\hline
\end{tabular}

LENGKUNG AYAKAN PASIR

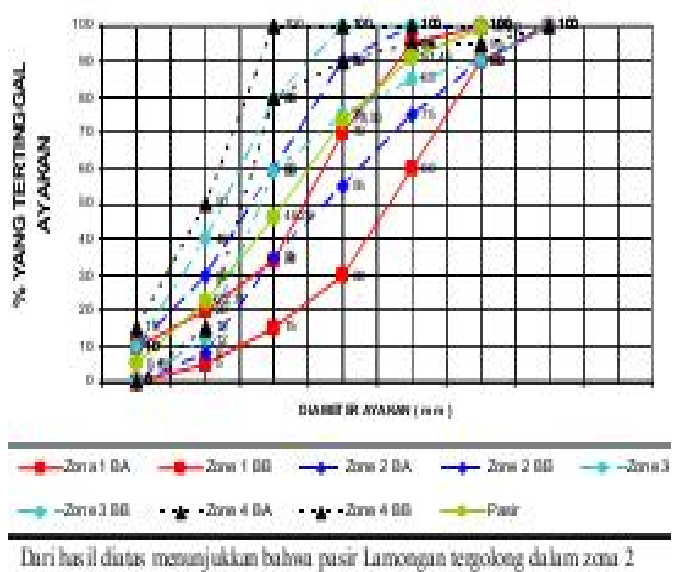

Gambar 6. Hasil uji fisik ayakan pasir Lamongan

\section{Analisa Ayakan Lusi}

Tabel 22. Hasil Uji Fisik Ayakan Lusi

\begin{tabular}{cccc}
\hline Diameter Ayakan & \multicolumn{3}{c}{ Lusi 1000 gram } \\
\hline $\mathrm{mm}$ & gram & $\%$ & $\mathrm{E} \%$ \\
\hline 4.76 & 22.1 & 2.21 & 2.21 \\
\hline 2.38 & 95.3 & 9.53 & 11.7 \\
\hline 1.19 & 157 & 15.7 & 27.4 \\
\hline 0.59 & 255 & 25.5 & 52.9 \\
\hline 0.3 & 309 & 30.9 & 83.8 \\
\hline 0.15 & 99.1 & 9.91 & 93.7 \\
\hline 0 & 63.1 & 6.31 & 100 \\
\hline Jumlah & 1000 & 100 & 372 \\
\hline & & Fkr $=$ & 3.72 \\
\hline
\end{tabular}

LENGKUNG AYAKANLUSI

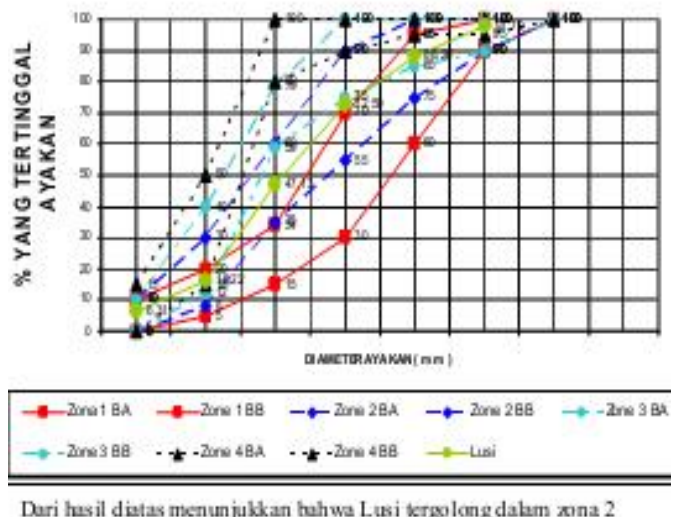

Gambar 7. Hasil uji fisik ayakan lusi 3. Analisa Ayakan Tanah Sawah 
Tabel 23. Hasil Uji Fisik Ayakan Tanah Sawah

\begin{tabular}{cccc}
\hline Diameter Ayakan & \multicolumn{3}{c}{ Tanah Sawah 1000 gram } \\
\hline mm & gram & $\%$ & E \% \\
\hline 4.76 & 10.9 & 1.09 & 1.09 \\
\hline 2.38 & 119 & 11.9 & 13.02 \\
\hline 1.19 & 180 & 18 & 30.98 \\
\hline 0.59 & 273 & 27.3 & 58.25 \\
\hline 0.3 & 266 & 26.6 & 84.88 \\
\hline 0.15 & 82.9 & 8.29 & 93.17 \\
\hline 0 & 68.3 & 6.83 & 100 \\
\hline Jumlah & 1000 & 100 & 381.39 \\
\hline & & Fkr $=$ & 3.81 \\
\hline
\end{tabular}

LENGKUNG AYAKAN TANAH SAWAH

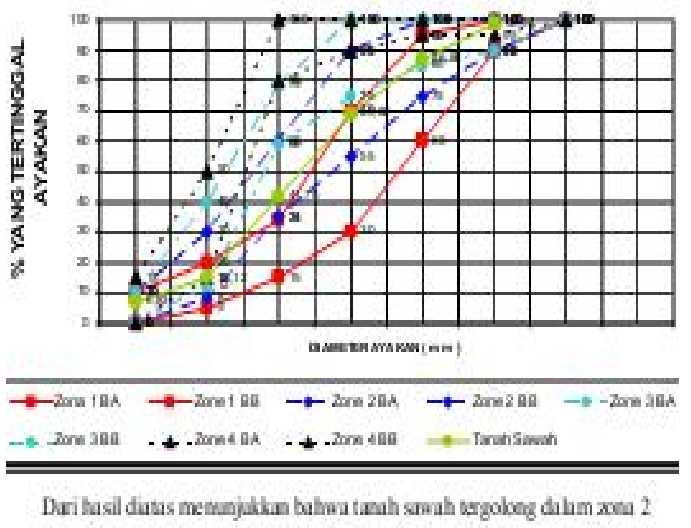

Gambar 8. Hasil uji fisik ayakan tanah sawah

4. Analisa Ayakan $40 \%$ lusi+60\% tanah sawah

Tabel 24. Hasil Uji Fisik Ayakan Campuran 40\%: $60 \%$

\begin{tabular}{cccc}
\hline Diameter Ayakan & \multicolumn{2}{c}{ Camp Komposisi 1000 gram } \\
\hline $\mathrm{mm}$ & gram & $\%$ & $\mathrm{E} \%$ \\
\hline 4.76 & 48.8 & 4.88 & 4.88 \\
\hline 2.38 & 78.6 & 7.86 & 12.74 \\
\hline 1.19 & 122 & 12.2 & 24.96 \\
\hline 0.59 & 314 & 31.4 & 56.32 \\
\hline 0.3 & 263 & 26.3 & 82.61 \\
\hline 0.15 & 115 & 11.5 & 94.09 \\
\hline 0 & 59.1 & 5.91 & 100 \\
\hline Jumlah & 1000 & 100 & 375.6 \\
\hline & & $\mathrm{Fkr}=$ & 3.76 \\
\hline
\end{tabular}

\section{LENGKUNG AYAKAN $40 \%$ LUSI+ 60\% T. SAWAH}

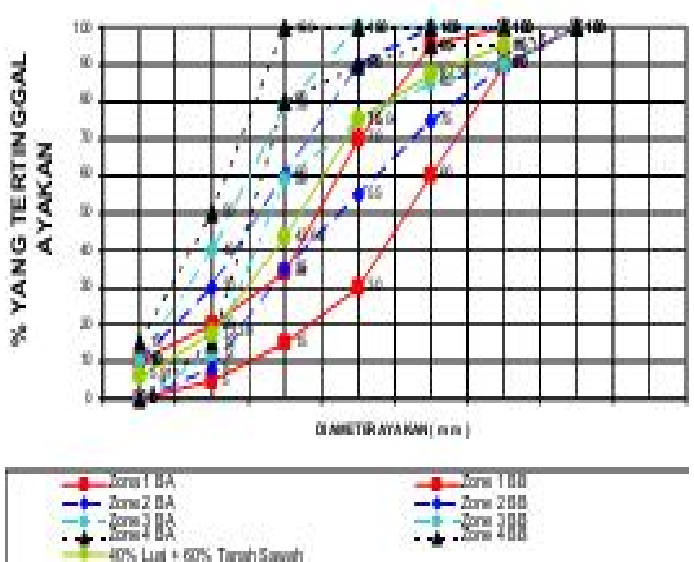

Gambar 9. Hasil uji fisik ayakan $40 \%$ : $60 \%$

5. Analisa Ayakan 50\% lusi+50\% tanah sawah

Tabel 25. Hasil Uji Fisik Ayakan Campuran 50\% : 50\%

\begin{tabular}{cccc}
\hline $\begin{array}{c}\text { Diameter } \\
\text { Ayakan }\end{array}$ & \multicolumn{3}{c}{ Camp Komposisi 1000 gram } \\
\hline $\mathrm{mm}$ & gram & $\%$ & $\mathrm{E} \%$ \\
\hline 4.76 & 39.7 & 3.97 & 3.97 \\
\hline 2.38 & 80.9 & 8.09 & 12.06 \\
\hline 1.19 & 147 & 14.7 & 26.79 \\
\hline 0.59 & 312 & 31.2 & 58.03 \\
\hline 0.3 & 139 & 13.9 & 81.92 \\
\hline 0.15 & 130 & 13 & 94.95 \\
\hline 0 & 50.5 & 5.05 & 100 \\
\hline Jumlah & 1000 & 100 & 377.72 \\
\hline & & $\mathrm{Fkr}=$ & 3.78 \\
\hline
\end{tabular}

LENGKUNG AYAKAN $50 \%$ LUSI+ $50 \%$ T. SAWAH

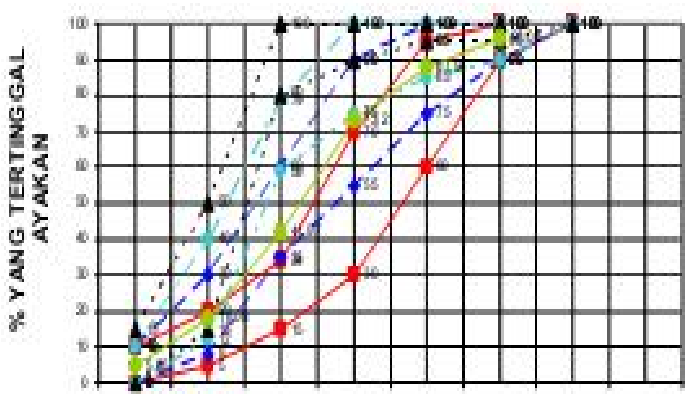

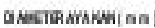

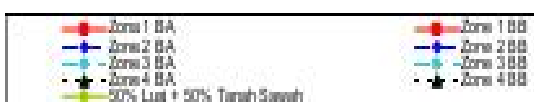

Gambar 10. Hasil uji fisik ayakan campuran $50 \%: 50 \%$ 
6. Analisa Ayakan 55\% lusi+45\% tanah sawah

Tabel 26. Hasil Uji Fisik Ayakan Campuran 55\%: $45 \%$

\begin{tabular}{cccc}
\hline $\begin{array}{c}\text { Diameter } \\
\text { Ayakan }\end{array}$ & \multicolumn{3}{c}{$\begin{array}{c}\text { Camp Komposisi } 1000 \\
\text { gram }\end{array}$} \\
\hline $\mathrm{mm}$ & gram & $\%$ & $\mathrm{E} \%$ \\
\hline 4.76 & 44.8 & 4.48 & 4.48 \\
\hline 2.38 & 88.1 & 8.81 & 13.29 \\
\hline 1.19 & 146 & 14.6 & 27.89 \\
\hline 0.59 & 290.5 & 29.1 & 56.94 \\
\hline 0.3 & 233 & 23.3 & 80.24 \\
\hline 0.15 & 142.8 & 14.3 & 94.52 \\
\hline 0 & 54.8 & 5.48 & 100 \\
\hline Jumlah & 1000 & 100 & 377.36 \\
\hline & & Fkr $=$ & 3.77 \\
\hline
\end{tabular}

\section{LENGKUNG AYAKAN $55 \%$ LUS|+ 45\% T. SAWAH}
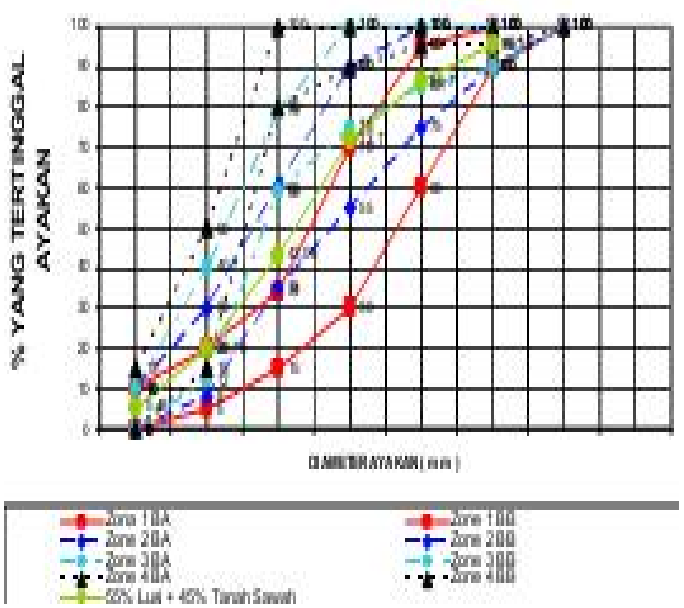

Gambar 11. Hasil uji fisik campuran $55 \%: 45 \%$

Dari hasil diatas menunjukkan bahwa Campuran 55\% Lusi $+45 \%$ Tanah Sawah tergolong dalam zona 2.

7. Analisa Ayakan $60 \%$ lusi+40\% tanah sawah
Tabel 27. Hasil Uji Fisik Ayakan Campuran 60\%: 40\%

\begin{tabular}{cccc}
\hline Diameter Ayakan & \multicolumn{2}{c}{ Camp Komposisi 1000 gram } \\
\hline $\mathrm{mm}$ & gram & $\%$ & $\mathrm{E} \%$ \\
\hline 4.76 & 39.6 & 3.96 & 3.96 \\
\hline 2.38 & 60.2 & 6.02 & 9.98 \\
\hline 1.19 & 136 & 13.6 & 23.59 \\
\hline 0.59 & 322 & 32.2 & 55.77 \\
\hline 0.3 & 247 & 24.7 & 80.42 \\
\hline 0.15 & 133 & 13.3 & 93.69 \\
\hline 0 & 63.1 & 6.31 & 100 \\
\hline Jumlah & 1000 & 100 & 367.41 \\
\hline & & Fkr $=$ & 3.67
\end{tabular}

\section{LENGKUNG AYAKAN $60 \%$ LUSI + 40\% T. SAWAH}

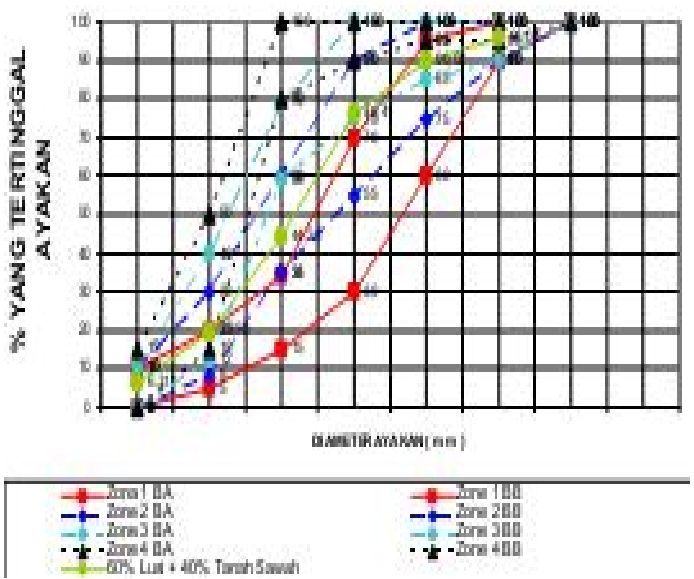

Gambar 12. Hasil uji fisik ayakan campuran $60 \%: 40 \%$

\subsection{Analisa Test Uji Resapan Mortar}

1. Mortar Dengan Komposisi Semen Murni

Tabel 28. Hasil Resapan Mortar

\begin{tabular}{cccc}
\hline \multirow{2}{*}{ Komposisi (\%) } & \multicolumn{2}{c}{ Berat } & Resapan \\
\cline { 2 - 4 } & $\begin{array}{c}\text { Basah } \\
(\mathrm{gr})\end{array}$ & $\begin{array}{c}\text { Kering } \\
(\mathrm{gr})\end{array}$ & $(\%)$ \\
\hline 40TS + 57LUSI + 3PC & 208.7 & 203.5 & 2.49 \\
\hline 40TS + 54LUSI + 6PC & 206 & 201.3 & 2.28 \\
\hline 40TS + 51LUSI + 9PC & 207.3 & 202.95 & 2.1 \\
\hline 45TS + 52LUSI + 3PC & 208.36 & 201.91 & 3.1 \\
\hline 45TS + 49LUSI + 6PC & 208 & 202.69 & 2.55 \\
\hline 45TS + 46LUSI + 9PC & 205.6 & 200.65 & 2.41 \\
\hline 50TS + 47LUSI + 3PC & 207.2 & 200.2 & 3.38 \\
\hline 50TS + 44LUSI + 6PC & 205.8 & 200.68 & 2.49 \\
\hline 50TS + 41LUSI + 9PC & 206.8 & 201.19 & 2.71 \\
\hline
\end{tabular}


resapan tiap komposisi mortar

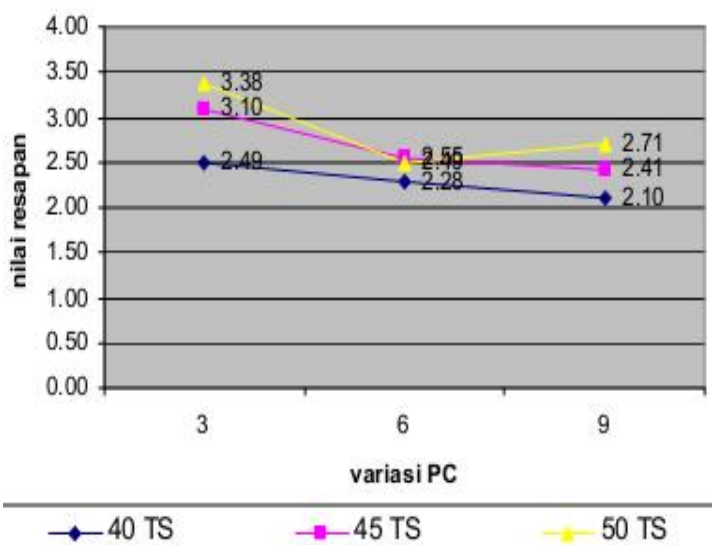

Gambar 13. Hubungan resapan pada mortar umur 28 hari dengan komposisi PC

a. Memperhatikan tabel 28 dan grafik 23 diperoleh variasi campuran bahan baku dasar tanah sawah $40 \%$. Untuk variasi $40 \mathrm{TS}+57$ LUSI +3 PC pada umur 28 hari diperoleh hasil resapan air pada mortar sebesar $2.49 \%$. Sedangkan untuk variasi $40 \mathrm{TS}+54 \mathrm{LUSI}+6 \mathrm{PC}$ pada umur 28 hari diperoleh hasil resapan air sebesar 2.28\%. Dan untuk variasi $40 \mathrm{TS}+51$ LUSI +9 PC pada umur 28 hari diperoleh hasil resapan air adalah sebesar $2.10 \%$.

b. Variasi campuran dengan dasar tanah sawah sebesar $45 \%$ dengan variasi 45 TS + 52 LUSI + 3 PC, pada umur 28 hari didapat resapan air pada mortar sebesar $3.10 \%$, sedangkan untuk variasi $45 \mathrm{TS}+49$ LUSI + 6 PC pada umur 28 hari didapat resapan air sebesar $2.55 \%$, dan untuk variasi campuran $45 \mathrm{TS}+$ 46 LUSI + 9 PC pada umur 28 hari didapat resapan air sebesar $2.41 \%$.

c. Variasi campuran dengan dasar tanah sawah sebesar $50 \%$, pada variasi 50 TS + 47 LUSI + 3 PC pada umur 28 hari didapat resapan air pada mortar sebesar $3.38 \%$, sedangkan untuk variasi $50 \mathrm{TS}+44 \mathrm{LUSI}+6 \mathrm{PC}$ pada umur 28 hari didapat banyak resapan air sebesar $2.49 \%$, dan untuk variasi $50 \mathrm{TS}+41 \mathrm{LUSI}+9$ PC pada umur 28 hari didapat resapan air sebesar $2.71 \%$.

d. Dapat disimpulkan bahwa daya resap air pada mortar dipengaruhi beberapa faktor, yakni dipengaruhi prosentase tanah sawah; semakin banyak tanah sawah akan semakin banyak air yang diserap mortar, selain itu dipengaruhi banyaknya PC pada mortar; semakin banyak PC pada mortar akan berbanding terbalik pada penyerapan air, semakin banyak PC maka semakin sedikit air yang terserap mortar. Setelah menganalisa hasil diatas didapat bahwa semakin sedikit PC dan semakin banyak tanah sawah akan semakin banyak resapan pada mortar, sedangkan semakin banyak PC dan semakin sedikit tanah sawah maka penyerapan air semakin sedikit. Variasi komposisi yang tepat adalah $40 \mathrm{TS}+54$ LUSI +6 $\mathrm{PC}$ dan $40 \mathrm{TS}+51 \mathrm{LUSI}+9 \mathrm{PC}$.

2. Mortar Dengan Komposisi Semen dan Penambahan Fly Ash

a. Tabel 29 dan grafik 14 menunjukkan gambaran variasi campuran bahan baku dan substitusi semen dengan fly ash sebesar $20 \%$ dengan komposisi variasi 40TS + $54 \mathrm{LUSI}+4.8 \mathrm{PC}+1.2 \mathrm{FA}$ pada umur 28 hari diperoleh hasil resapan 
air pada mortar sebesar $3.42 \%$. Sedangkan untuk variasi 40TS + $51 \mathrm{LUSI}+7.2 \mathrm{PC}+1.8 \mathrm{FA}$ pada umur 28 hari diperoleh hasil resapan air sebesar 3.49\%.b. Variasi campuran dengan komposisi subsitusi semen dengan fly ash sebesar $50 \%$ dengan komposisi $40 \mathrm{TS}+54 \mathrm{LUSI}+3 \mathrm{PC}+3 \mathrm{FA}$, pada umur 28 hari didapat resapan air pada mortar sebesar $4.09 \%$, sedangkan untuk variasi 40TS + $51 \mathrm{LUSI}+4.5 \mathrm{PC}+4.5 \mathrm{FA}$ pada umur 28 hari didapat resapan air sebesar $4.36 \%$.

Tabel 29. Komposisi Semen dan Penambahan Fly Ash

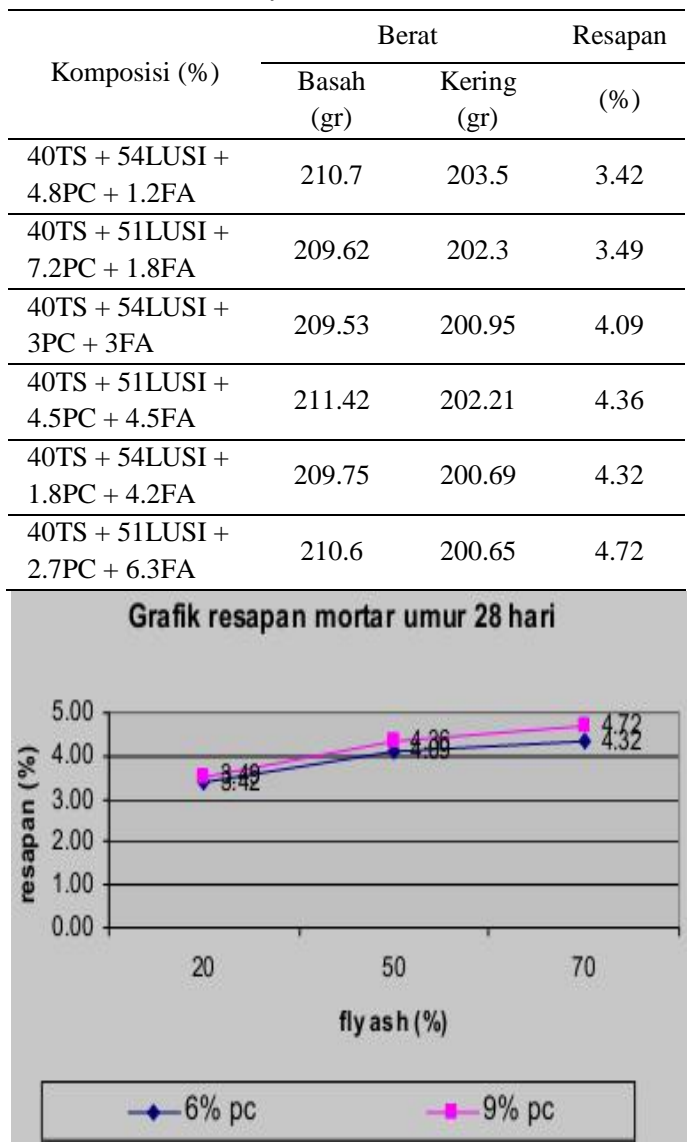

Gambar 14. Grafik hubungan resapan pada mortar dengan penambahan fly ash umur 28 hari c. Variasi campuran substitusi semen dengan fly ash $70 \%$, pada variasi $40 \mathrm{TS}+54 \mathrm{LUSI}+1.8 \mathrm{PC}+4.2 \mathrm{FA}$ pada umur 28 hari didapat resapan air pada mortar sebesar $4.32 \%$, sedangkan variasi 40TS + 51LUSI + $2.7 \mathrm{PC}+6.3 \mathrm{FA}$ pada umur 28 hari didapat resapan air sebesar $4.72 \%$.

d. Semakin banyak PC pada mortar semakin sedikit air yang terserap mortar dan semakin banyak fly ash akan semakin banyak air yang terserap mortar. Setelah menganalisa hasil diatas didapat bahwa semakin sedikit PC dan semakin banyak fly ash akan semakin banyak resapan mortar, sedangkan semakin banyak PC dan semakin sedikit fly ash maka penyerapan air pada mortar akan semakin sedikit.

\subsection{Analisa Test Uji Kuat Tekan Mortar}

Dari semua data yang diterima didapat hasil kuat tekan mortar pada umur 7, 14, 28 hari sebagai berikut:

1. Mortar Dengan Komposisi Semen Murni

Tabel 30. Hasil Kuat Tekan Uji Mortar dengan Semen Murni

\begin{tabular}{cccccc}
\hline \multicolumn{2}{c}{ Perbandingan Material } & \multicolumn{3}{c}{ Kuat Tekan Kg/Cm } \\
\hline $\begin{array}{c}\text { Lusi } \\
(\mathrm{gr})\end{array}$ & PC(gr) & $\begin{array}{c}\text { Tnh } \\
\text { Swh } \\
(\mathrm{gr})\end{array}$ & $7 \mathrm{hr}$ & $14 \mathrm{hr}$ & $\begin{array}{c}28 \\
\mathrm{hr}\end{array}$ \\
\hline 570 & 30 & 400 & 5.80 & 7.25 & 10.4 \\
\hline 540 & 60 & 400 & 14.26 & 16.25 & 25.3 \\
\hline 510 & 90 & 400 & 17.89 & 20.05 & 32.5 \\
\hline 520 & 30 & 450 & 4.70 & 7.32 & 9.58 \\
\hline 490 & 60 & 450 & 10.23 & 13.24 & 22.6 \\
\hline 460 & 90 & 450 & 12.56 & 15.89 & 25.4 \\
\hline 470 & 30 & 500 & 3.54 & 6.20 & 8.74 \\
\hline 440 & 60 & 500 & 11.04 & 13.47 & 23.5 \\
\hline 410 & 90 & 500 & 11.65 & 14.25 & 24.5 \\
\hline
\end{tabular}




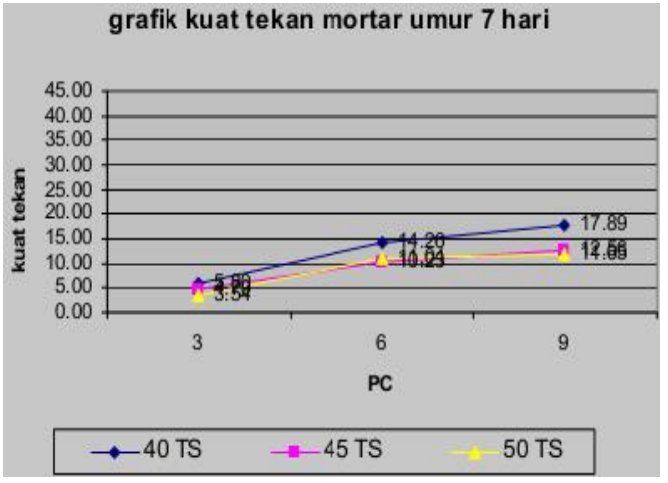

Gambar 15. Grafik hubungan kuat tekan mortar dengan umur 7 hari

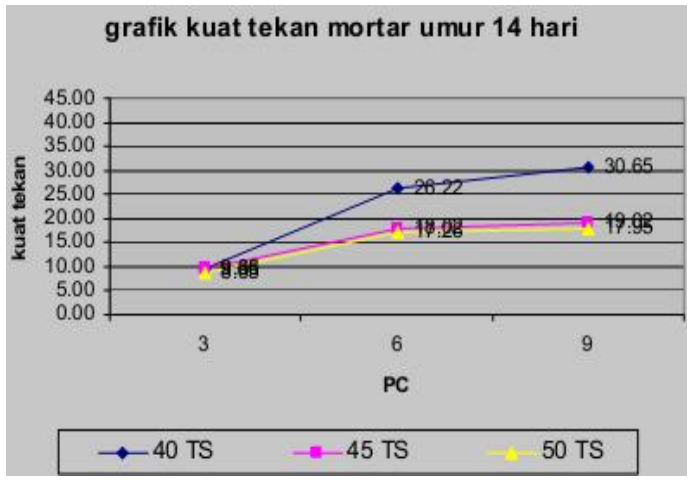

Gambar 16. Grafik hubungan kuat tekan mortar dengan umur 14 hari

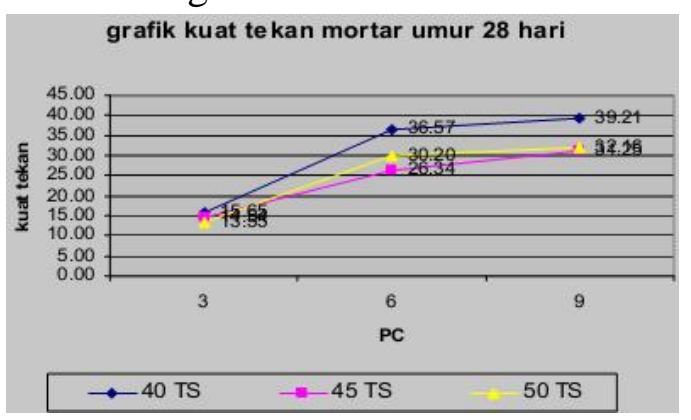

Gambar 17. Grafik hubungan kuat tekan mortar dengan umur 28 hari

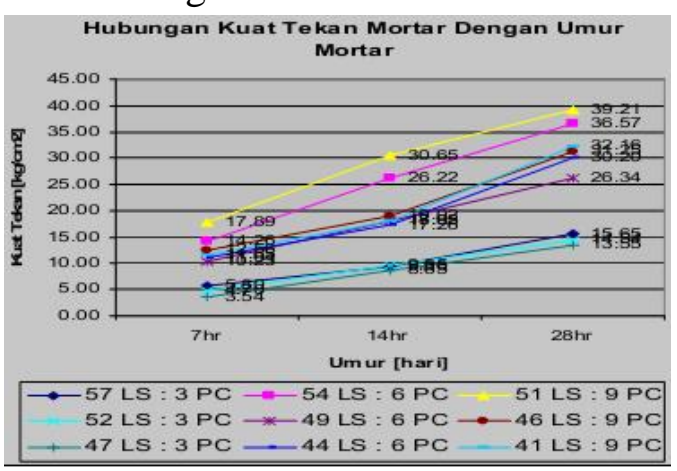

Gambar 18. Grafik hubungan kuat tekan mortar dengan umur 7, 14 dan 28 hari
Untuk membaca analisa kuat tekan kita perhatikan tabel 30, gambar 15 , gambar 16, gambar 17 dan gambar 18 dimana kita bisa hubungkan analisa antara kuat tekan benda uji dengan umur mortar. Untuk kuat tekan benda uji kita buat umur 7, 14, dan 28 hari dengan komposisi campuran:

$40 \mathrm{TS}+57 \mathrm{LS}+3 \mathrm{PC}$

$40 \mathrm{TS}+54 \mathrm{LS}+6 \mathrm{PC}$

$40 \mathrm{TS}+51 \mathrm{LS}+9 \mathrm{PC}$

$45 \mathrm{TS}+52 \mathrm{LS}+3 \mathrm{PC}$

$45 \mathrm{TS}+49 \mathrm{LS}+6 \mathrm{PC}$

$45 \mathrm{TS}+46 \mathrm{LS}+9 \mathrm{PC}$

$50 \mathrm{TS}+47 \mathrm{LS}+3 \mathrm{PC}$

$50 \mathrm{TS}+44 \mathrm{LS}+6 \mathrm{PC}$

$50 \mathrm{TS}+41 \mathrm{LS}+9 \mathrm{PC}$

a. Komposisi campuran 40TS + 57LS + 3PC memiliki kuat tekan pada umur 7 hari sebesar $5,80 \mathrm{Kg} / \mathrm{Cm}^{2}$, nilai kuat tekan umur 14 hari sebesar 7,25 $\mathrm{Kg} / \mathrm{Cm}^{2}$, dan nilai kuat tekan umur 28 hari sebesar 10,35 $\mathrm{Kg} / \mathrm{Cm}^{2}$.

b. Komposisi 40TS + 54LS + 6PC memiliki kuat tekan pada umur 7 hari sebesar $14,26 \mathrm{Kg} / \mathrm{Cm}^{2}$, nilai kuat tekan umur 14 hari sebesar $16,25 \mathrm{Kg} / \mathrm{Cm}^{2}$, dan nilai kuat tekan 28 hari sebesar $25,32 \mathrm{Kg} / \mathrm{Cm}^{2}$.

c. Penambahan 40TS + 51LS + 9PC memiliki kuat tekan umur 7 hari sebesar $17,89 \mathrm{Kg} / \mathrm{Cm}^{2}$, nilai kuat tekan umur 14 hari sebesar 20,05 $\mathrm{Kg} / \mathrm{Cm}^{2}$, dan nilai kuat tekan 28 hari sebesar $32,54 \mathrm{Kg} / \mathrm{Cm}^{2}$.

d. Penambahan 45TS + 52LS + 3PC memiliki kuat tekan umur 7 hari sebesar 4,70 $\mathrm{Kg} / \mathrm{Cm}^{2}$, nilai kuat tekan umur 14 hari sebesar 7,32 $\mathrm{Kg} / \mathrm{Cm}^{2}$, dan nilai kuat tekan umur 
28 hari sebesar 9,58 Kg/Cm².

e. Komposisi $45 \mathrm{TS}+49 \mathrm{LS}+6 \mathrm{PC}$ memiliki kuat tekan umur 7 hari sebesar $10,23 \mathrm{Kg} / \mathrm{Cm}^{2}$, nilai kuat tekan umur 14 hari sebesar 13,24 $\mathrm{Kg} / \mathrm{Cm}^{2}$ dan nilai kuat tekan 28 hari sebesar 22,56 Kg/Cm².

f. Penambahan 45TS + 46LS + 9PC memiliki kuat tekan umur 7 hari sebesar $12,56 \mathrm{Kg} / \mathrm{Cm}^{2}$, nilai kuat tekan umur 14 hari sebesar 15,89 $\mathrm{Kg} / \mathrm{Cm}^{2}$ dan kuat tekan umur 28 hari sebesar $25,36 \mathrm{Kg} / \mathrm{Cm}^{2}$.

g. Komposisi campuran 50TS + 47LS + 3PC memiliki kuat tekan pada umur 7 hari sebesar $3,54 \mathrm{Kg} / \mathrm{Cm}^{2}$, nilai kuat tekan umur 14 hari sebesar $6,20 \mathrm{Kg} / \mathrm{Cm}^{2}$, dan nilai kuat tekan umur 28 hari sebesar 8,74 $\mathrm{Kg} / \mathrm{Cm}^{2}$

h. Komposisi 50TS + 44LS + 6PC memiliki kuat tekan pada umur 7 hari sebesar $11,04 \mathrm{Kg} / \mathrm{Cm}^{2}$, nilai kuat tekan umur 14 hari sebesar $13,47 \mathrm{Kg} / \mathrm{Cm}^{2}$, dan nilai kuat tekan 28 hari sebesar $23,54 \mathrm{Kg} / \mathrm{Cm}^{2}$.

i. Penambahan 50TS + 41LS + 9PC memiliki kuat tekan umur 7 hari sebesar $11,65 \mathrm{Kg} / \mathrm{Cm}^{2}$, nilai kuat tekan umur 14 hari sebesar 14,25 $\mathrm{Kg} / \mathrm{Cm}^{2}$, dan nilai kuat tekan 28 hari sebesar $24,52 \mathrm{Kg} / \mathrm{Cm}^{2}$.

Dari analisa diatas dapat disimpulkan bahwa semakin lama perendaman maka semakin solid pengikatan semen yang dapat mengakibatkan kuat tekan yang semakin tinggi pula.

2. Mortar Dengan Komposisi Semen dan Penambahan Fly Ash
Tabel 31. Komposisi Semen dan Penambahan Fly Ash

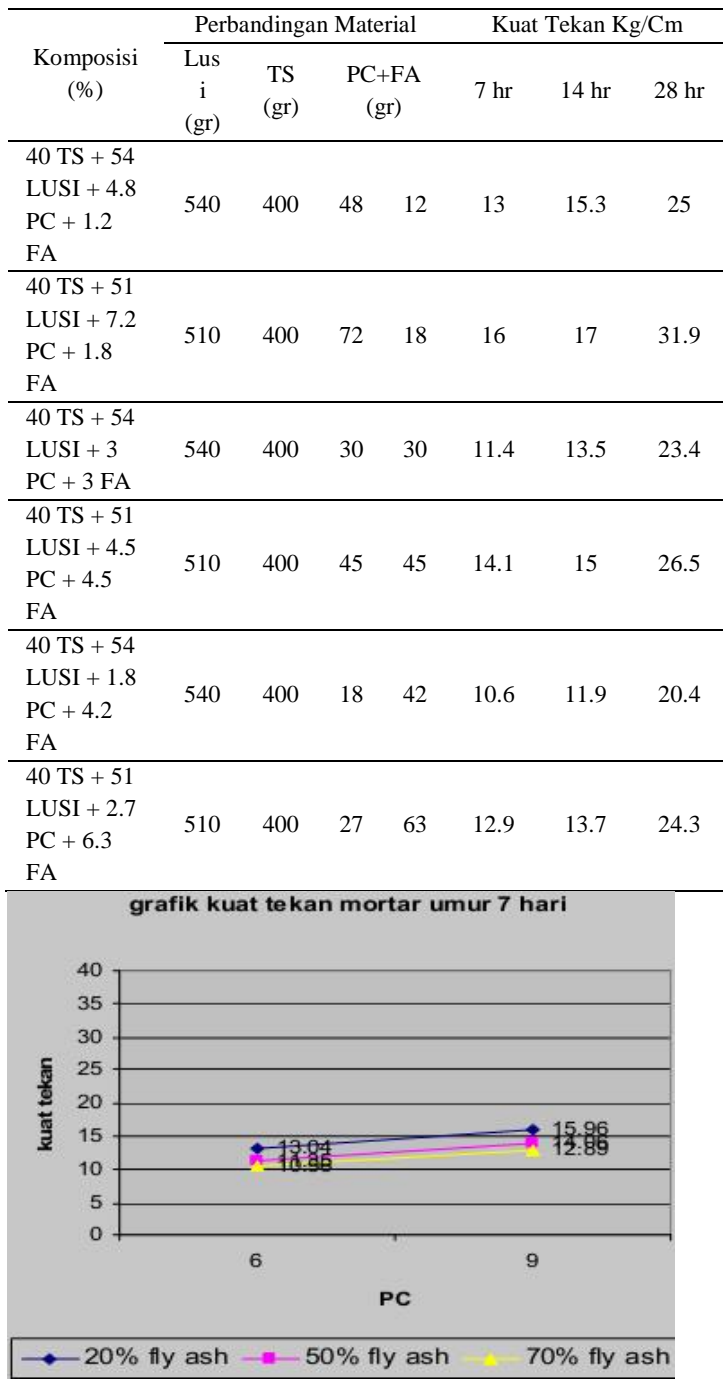

Gambar 19. Grafik hubungan kuat tekan mortar dengan penambahan fly ash umur 7 hari

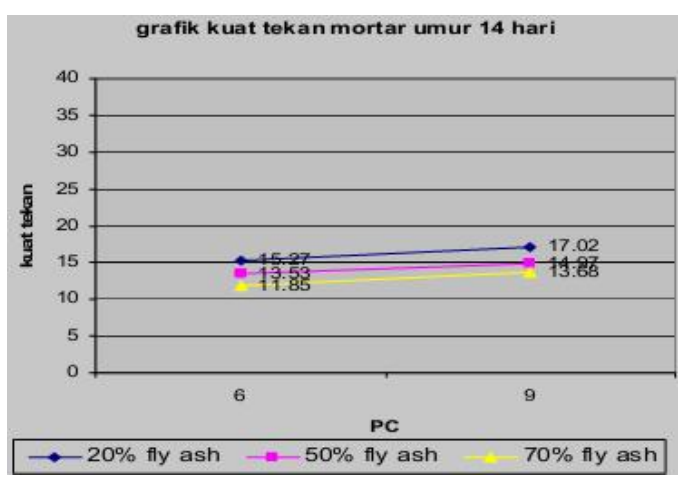

Gambar 20. Grafik hubungan kuat tekan mortar dengan penambahan fly ash umur 14 hari 


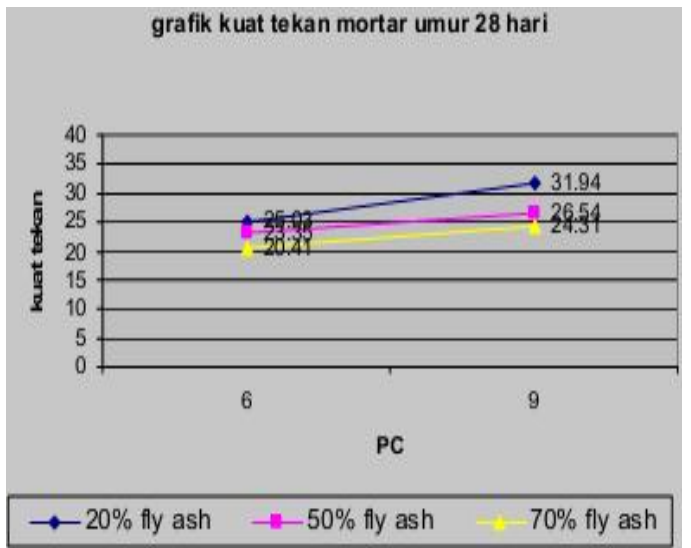

Gambar 21. Grafik hubungan kuat tekan mortar dengan penambahan fly ash umur 28 hari

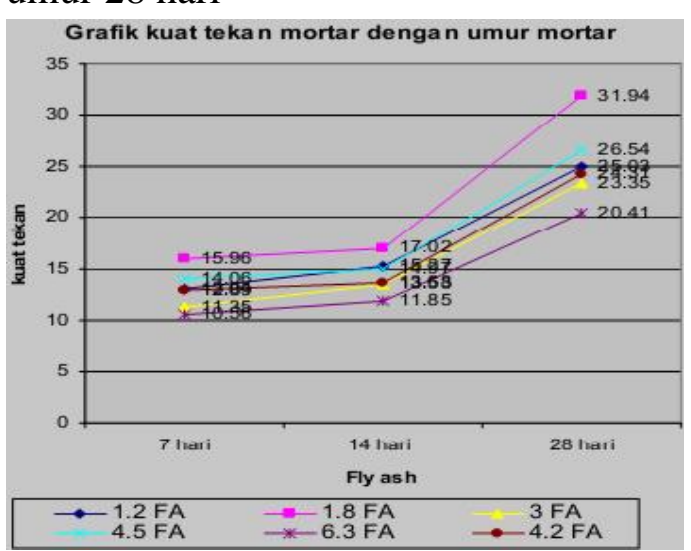

Gambar 22. Grafik hubungan kuat tekan mortar dengan penambahan fly ash umur 7, 14 dan 28 hari

Untuk membaca analisa kuat tekan kita perhatikan tabel 31, Gambar 19, gambar 20 dan gambar 21 dimana kita bisa hubungkan analisa antara kuat tekan benda uji dengan umur mortar. Untuk kuat tekan benda uji kita buat umur 7,14 dan 28 hari dengan komposisi campuran:

Substitusi semen 20\%:

$40 \mathrm{TS}+54 \mathrm{LS}+4.8 \mathrm{PC}+1.2 \mathrm{FA}$

$40 \mathrm{TS}+51 \mathrm{LS}+7.2 \mathrm{PC}+1.8 \mathrm{FA}$

Substitusi semen 50\%:

$40 \mathrm{TS}+54 \mathrm{LS}+3 \mathrm{PC}+3 \mathrm{FA}$

$40 \mathrm{TS}+51 \mathrm{LS}+4.5 \mathrm{PC}+4.5 \mathrm{FA}$
Substitusi semen 70\%:

$40 \mathrm{TS}+54 \mathrm{LS}+1.8 \mathrm{PC}+4.2 \mathrm{FA}$

$40 \mathrm{TS}+51 \mathrm{LS}+2.7 \mathrm{PC}+6.3 \mathrm{FA}$

a. Pada komposisi campuran 40TS + $54 \mathrm{LS}+4.8 \mathrm{PC}+1.2 \mathrm{FA}$ memiliki kuat tekan pada umur 7 hari sebesar $13.04 \mathrm{Kg} / \mathrm{Cm}^{2}$, nilai kuat tekan umur 14 hari sebesar $15.27 \mathrm{Kg} / \mathrm{Cm}^{2}$ dan kuat tekan umur 28 hari sebesar $25.03 \mathrm{Kg} / \mathrm{Cm}^{2}$.

b. Komposisi 40TS + 51LS + 7.2PC + 1.8FA memiliki kuat tekan pada umur 7 hari sebesar $15.96 \mathrm{Kg} / \mathrm{Cm}^{2}$, nilai kuat tekan umur 14 hari sebesar $17.02 \mathrm{Kg} / \mathrm{Cm}^{2}$ dan kuat tekan umur 28 hari sebesar 31.94 $\mathrm{Kg} / \mathrm{Cm}^{2}$.

c. Penambahan 40TS + 54LS + 3PC + 3FA memiliki kuat tekan umur 7 hari sebesar $11.35 \mathrm{Kg} / \mathrm{Cm}^{2}$, nilai kuat tekan umur 14 hari sebesar $13.53 \mathrm{Kg} / \mathrm{Cm}^{2}$ dan kuat tekan umur 28 hari sebesar $23.35 \mathrm{Kg} / \mathrm{Cm}^{2}$.

d. Penambahan 40TS + 51LS + 4.5PC +4.5 FA memiliki kuat tekan umur 7 hari sebesar $14.06 \mathrm{Kg} / \mathrm{Cm}^{2}$, nilai kuat tekan umur 14 hari sebesar $14.97 \mathrm{Kg} / \mathrm{Cm}^{2}$ dan kuat tekan umur 28 hari sebesar $26.54 \mathrm{Kg} / \mathrm{Cm}^{2}$.

e. Komposisi 40TS + 54LS + 1.8PC + 4.2 FA memiliki kuat tekan umur 7 hari sebesar $10.56 \mathrm{Kg} / \mathrm{Cm}^{2}$, nilai kuat tekan umur 14 hari sebesar $11.85 \mathrm{Kg} / \mathrm{Cm}^{2}$ dan kuat tekan umur 28 hari sebesar $20.41 \mathrm{Kg} / \mathrm{Cm}^{2}$.

f. Penambahan 40TS + 51LS + 2.7PC +6.3 FA memiliki kuat tekan umur 7 hari sebesar $12.89 \mathrm{Kg} / \mathrm{Cm}^{2}$, nilai kuat tekan umur 14 hari sebesar $13.68 \mathrm{Kg} / \mathrm{Cm}^{2}$ dan kuat tekan umur 28 hari sebesar $24.31 \mathrm{Kg} / \mathrm{Cm}^{2}$. 


\section{Simpulan}

1. Dari data hasil tes uji kuat tekan komposisi semen murni diatas maka:

- Didapat hasil kuat tekan maksimum mortar pada campuran 40\% TS : $51 \%$ LS : 9\%PC pada umur 28 hari sebesar $32.54 \mathrm{~kg} / \mathrm{cm}^{2}$ dan nilai resapan sebesar $2.10 \%$, cocok digunakan sebagai genteng ringan, paving mutu rendah, beton ringan

- Didapat hasil kuat tekan minimum mortar pada campuran 50\% TS : 47\% LS : 3\%PC pada umur 28 hari sebesar $8.74 \mathrm{~kg} / \mathrm{cm}^{2}$ dan nilai resapan sebesar $3.38 \%$.

2. Analisa test uji kuat tekan mortar dengan penambahan fly ash sebagai substitusi semen adalah:

- Kuat tekan tertinggi dicapai pada komposisi 40\%TS : 51\%LS : $7.2 \% \mathrm{PC}: 1.8 \mathrm{FA}$ sebesar, 31.94 $\mathrm{kg} / \mathrm{cm}^{2}$ dan nilai resapan sebesar $3.49 \%$.

- Kuat Tekan terendah dicapai pada komposisi 40\%TS : 54\%LS : 1.8\%PC : $4.2 \%$ FA yaitu sebesar $20.41 \mathrm{~kg} / \mathrm{cm}^{2}$ dan nilai resapan sebesar $4.32 \%$.

- Semakin besar variabel PC dan semakin kecil variabel FA, maka semakin besar pula kuat tekan yang didapat.

\section{Daftar Pustaka}

Braja M.Das. terjemahan Noor Endah,

Mochtar Indrasurya B. 1991.

Mekanika Tanah jilid 1 (Prinsip-

Prinsip Rekayasa Geotehnis).

Jakarta: Erlangga.
Mochamad Syaifudin, Yala N Wahyu, ITS. 2007. Pengaruh Abu Batu Dan Fly Ash Terhadap Kuat Tekan Dan Resapan Dalam Pembuatan Paving Block. Surabaya.

Nurakumala Arya, ITS, Evaluasi Kuat Tekan. 2007. Resapan Mortar Dari Lumpur PDAM Karang Pilang Sebagai Study Awal Batu Bata NonBakar, Surabaya.

Rifai Bachtiar, Mahardika Lendi, ITS. 2007. Pembuatan Batu Bata Dari Lumpur Sidoarjo Dengan Variasi Penambahan Tanah Sawah Dan Abu Ampas Tebu. Surabaya.

Suaduon Jogie, Setiantoro Agung, ITS. 2007. Pembuatan Batu Bata Dan Limbah Lumpur Lapindo Dengan Penambahan Tanah Sawah. Surabaya.

Standar Industri Indonesia (SII) 028580. 1980. Mutu dan cara uji Bata Beton Berlubang. Departemen Perindustrian Republik Indonesia.

Standar Nasional Indonesia (SNI) 030096-1995. 1995. Mutu dan Cara Uji Genteng Beton. Departemen Perindustrian Republik Indonesia.

Standar Nasional Indonesia (SNI) 030349-1989. 1989. Bata Beton untuk Pasangan Dinding. Departemen Perindustrian Republik Indonesia.

Standar Nasional Indonesia (SNI) 152531-1991. 1991. Metode Pengujian Berat Jenis Semen Portland. Departemen Perindustrian Republik Indonesia.

Standar Nasional Indonesia (SNI) 030691-1996. 1996. Bata Beton Untuk Lantai (Paving Block). Departemen Perindustrian Republik Indonesia. 
Standar Nasional Indonesia (SNI) 150302-1999. 1999. Semen Portland Pozolan. Departemen Perindustrian Republik Indonesia.

Standar Nasional Indonesia (SNI) 036825- 2002. 2002. Metode Pengujian Kekuatan Tekan Mortar Semen Portland Untuk Pekerjaan Sipil. Departemen Perindustrian Indonesia.

Standar Industri Indonesia (SII) 028480. 1980. Mutu Dan Cara Uji Bata Beton Pejal. Departemen Perindustrian Indonesia. 